\title{
Dichotomy of Believing and Belonging - An Irish Context
}

\author{
Kerry Gallagher \\ Department of Sociology, National University of Ireland Maynooth \\ Auxilia House, Sociology Dept. NUI Maynooth, Maynooth, Co. Kildare, Ireland \\ Email: kerry.gallagher@nuim.ie
}

\begin{abstract}
:
Religion, in both the sense of the institution and religious practices, is embedded in society the social forms of religious life are fully integrated into the structures of society. Secularization is a source of great debate, and is a prominent feature in the sociology of religion literature. The need to examine the extent to which Catholicism in Ireland has been affected by the secular movement that has swept through Western Europe is essential to understanding religion in contemporary society, and the everyday meanings people attach to religious objects/institution/terminology at the local level. Through a close micro study of a small Donegal community I examine patterns of religious belief and practice and how these have undergone change in response to wider socio-cultural transformations associated with such things as urbanization and globalization. I therefore, establish the community's level of religiosity - from spirituality to practice. From this, a test of the applicability of Davies (1994) 'believing without belonging' theory to the local Irish case is conducted.
\end{abstract}

Keywords: Religion, Secularization, Rural Ireland, Religiosity, Religious practice 


\section{Introduction}

This research "dichotomy of believing and belonging - An Irish context" is a local level community study that attempts to situate the secularisation process at a micro level. This research will contribute to a clear understanding of the actual penetration of secularisation at the local parish and lived experience level. National level research fails to take into account the lived experience of religion and the religiosity of communities that could to some extent contradict the secularisation trend within Ireland. Furthermore, I propose to test the application of Davies (1994) 'Believing without belonging' theory to the analysis of the current rural religious situation in Co. Donegal. This added dimension could provide a basis for which this situation can be analysed and explicated.

This qualitative research involved interviewing sixteen people from the parish of Conwall and Leck in Letterkenny, Co. Donegal. The purpose of this research is to establish the extent of religiosity and faith possessed at a local rural area, opposed to data portrayed from research conducted at a national or European level. Semi-structured interviews were conducted and various elements of faith and religiosity were teased out and discussed; the topics ranged from mass/parish group activities, meanings attached to each, socialisation into the catholic way of thinking, influences, generation differences and personal opinions regarding secularisation and the Catholic Church in Ireland today. Grace Davies (1994) 'believing without belonging' argument provides a framework from which the analysis of my data can proceed.

This research contributes to the Sociology of religion literature in that it provides a different perspective on the secularisation debate in Ireland. National and international research cannot account for, or illustrate the meaning and attachment of rural communities to the Catholic Church. Therefore, this research examines the local lived experience of religion and will demonstrate whether religion is strong in this part of Ireland and if so, perhaps, micro level research could counteract claims of general secularisation throughout Ireland.

\section{Introduction to the Secularization Thesis}

Contemporary thinking with regards to religion is that the institution is dead or very much in decline. The extent of religiosity possessed in everyday life, for example, has to some degree changed since the nineteenth century. Many have assumed that societies were following a trajectory which emerged with modernisation. Attempts to characterise this shift has been an arduous task for theologians and social scientists. The fact that religion is still present within society has hindered theorists' attempts to explain this phenomenon. It has further resulted in some revoking their support of the secularisation theory. Most notably was Peter Berger (1990), a prominent American sociologist, who retracted his previous secularisation claims. The ambiguous nature of the concept 'secularisation' has hindered the definition and subsequently the application of the concept exclusively.

\subsection{Secularisation Debate}

Secularisation thesis is a prominent debate in the religious literature (Weber 1958(1930); Troeltsch 1958; Wilson 1985; Berger 1967; Luckmann 1967). Europe and America appeared 
to be emerging from the chains of that old-time religion, developing increasingly secular with modernisation. The secular age had arrived. This thought was shared by social scientists and theologians alike. Ever since the seminal thinkers of the nineteenth century hypothesized the decline in importance of religion as the industrial society emerged, inevitable, there would be a separation of church and state (Wallace 1966). C. Wright Mills (1959) captures this transformation when he wrote -

"Once the world was filled with the sacred - in thought, practice, and institutional form. After the Reformation and the Renaissance, the forces of modernization swept across the globe and secularization, a corollary historical process, loosened the dominance of the sacred. In due course, the sacred shall disappear altogether except, possibly, in the private realm.” (p. 32-33)

\subsubsection{Age of Faith}

The premise of the secularisation thesis is related to the idea of the 'Age of Faith'.

To state that secularisation is underway a point of reference to a period that was extremely religious and faithful needs to be made. The period often referred to is the Middle Ages. However, it would appear that the secularisation thesis has overstated the importance of religion in the past. The 'Age of Faith' has been questioned many times. Franklin Baumer (1960) emphasised that "contrary to popular supposition there was plenty of scepticism in the Middle Ages, and some of it was quite radical" (p.99). Organised religion and blind unquestioned faith during this period is a myth. However, that is not to say that the Middle Ages were a religious-less sceptical secular society. It was not. The argument is based on the fact that the extent of their faith is quite exaggerated. Furthermore, in terms of institutional participation Bruce (1997) posits that the 'Age of Faith' was a mere legend. In saying that, however, faith in the supernatural existed in medieval societies so surely they can be classified as religious? People in this period must still be regarded as religious as they did possess levels of faith; their religious beliefs may be somewhat vague and included magic but through belief, rather than participation, these were religious societies (Duffy 1992). Furthermore, this situation corresponds with Davies (1994) 'believing without belonging' theory which is quite intriguing - could this trend have been a trajectory from the Middle ages?

\section{2 Religion within the Secularization Realm}

Religion is a seminal concept that, like the secularisation concept, is quite difficult to define or to provide an all-encompassing definition for. Prominent theorists in the Sociology of Religion literature such as Durkheim associate religion with morality and Weber links religion to metaphysical explanations. Berger, who extends from the Durkheim school of thought, is influential in situating my research in the religion-secularisation literature. The complex breakdown of the interaction between religion, the individual and society which is permitted through the self-externalising and internalising is a unique process for which religion, its role and effects on society at a macro and micro level can be observed. The manifestation of the influence each has on the different spheres; how co-existence operates 
within the societal sphere is an apparent focus for the dynamics of these relationships in my case study area. Berger disputes that the greatest task facing religious legitimation is the issue of theodicy. Modernization brings with it graver dilemmas for religious legitimation. Industrialization, rise of Protestantism, religious pluralism is all challenges faced by religion. For Berger (1990) "Pluralism is a social-structure correlate of the secularization of consciousness” (P.127).

\section{3 Dobbelaere's Three Part Analytical Frame Work}

The religious institution, nowadays, in its structural form does not have the capability or power to contain or control individuals. Religious participation can no longer be the sole religious identifier but rather a deeper understanding of one's spirituality and the meanings that one attaches to religion and religious elements within society. The two mutually exclusive elements - believing and belonging - that once established an individual's religiosity and determined their level of faith have been separated by the modernization process. Although a strong element of this dichotomy features in the secularization literature it also is prominent in contemporary religious literature to rationalize and explain the emergence of new religious movements and the importance of spirituality. The decline in 'community' or the so-called shift from community to society and furthermore, the expression of religion from the public to the private sphere is key to the understanding of secularization. Dobbelaere moves beyond Berger's analysis of the legitimation, plausibility and the role these have for maintaining religions grip on the individual and society. Dobbelaere's three part analytical framework - the macro, the meso and the micro contextualize my research. Moreover, my research regarding a close examination of religiosity at a community based level and whether people believe without belonging or belong without believing could challenge Dobbelaere's three levels of analysis. Perhaps the breakdown of the functionally differentiated society, as postulated by Dobbelaere (1999), can explain the divergence of belief and belonging within the secularization context.

The autonomization at the societal level impacts on the societal sub-systems (Dobbelaere 1999) that increases the disengagement of individuals to the traditionally prescribed teachings of the church. Secularization is situated within this process as decline in church authority diminishes the importance of religion and increases functional rationality. As Weber (1958) states, the economy lost its religious ethos. The societalisation of the subsystems further impacts on the micro level, i.e. the consciousness of the individual in that one may lose the understanding of a sacred reality, or as Berger terms it, the 'internalization and self externalizing process' of this new secular language and environment.

The meso level witnesses the pluralisation of religions and the opening of the religious market to compete for individuals. Berger (1967) views this as a negative feature for the religious institutions as the religious message is "'de-objectivated', and more generally, the pluralistic situation...ipso facto plunges religion into crisis credibility” (P.150-151). The micro level introduces the privatization of religion - the individualization. Functional differentiation has stimulated individualization of choices and this has had its impact on the life world (Dobbelaere 1999). The pluralistic religious market combined with 
individualization leads to religious 'bricolage' - an individual patchwork or recomposition (Dobbelaere 1985). Religion á la carte is a common feature of society - According to the European Value Study about 20\% mix Christian beliefs (Inglis 1998)). These processes, it could be argued, further enhance the disengagement of believing and belonging as people adhere to the adhoc teachings that they find relevant or suitable to their current lifestyle.

There are clear links between the macro and micro levels. The direction of the casual relationships is not unidirectional but rather dialectical, e.g. between generalization on the macro level, pluralism on the meso level, but also between secularization and individual religiosity: growing disbelief may produce a manifesting process of secularization on the macro level. It is possible, thus, to suggest the link between the relationships that Dobbelaere illustrates and the applicability of these to my research. However, my research may contest/expand the secularization processes on each level.

The discourses that have surrounded secularization theories and debates have been controversial, topical and highly contentious. However, in retrospect a new climate has emerged that cannot and must not be circumvented; secularization can explain a decline in religiosity that is occurring in Western Europe, but secularization itself is shaped and maintained at different levels through different societal processes. Religion, its role and impact at a micro level, must not be underestimated.

\section{4 Secularisation - The Irish Context}

Ireland is said to be an anomaly to the rest of Western Europe with regards to the secularisation movement that has swept throughout developed countries. The Catholic Church remains the single largest church in Ireland with identification and attendance rates relatively high especially in comparison to other developed countries (Inglis 2007). This masquerade's the underlying decline in overall religiosity in Ireland. Irrelevant of cross-cultural comparisons the fact remains that nationally church attendance has declined significantly. This trend needs to be addressed at a local community level in order to get a complete synoptic perspective of the actual developments transpiring within Ireland, and perhaps acquire a greater understanding of whether some places or communities are indeed more resistant to this secular movement.

In doing this, one must examine contemporary Catholicism in Ireland, what it means to be a catholic in twenty-first century Ireland and the shift of religion from the public to the private sphere. This shift, identified by Parsons (1974), Berger and Luckmann (1966), insinuates the public relevance of traditional religion has been lost and as it is now the primary concern of the individual, it will be confined to the private sphere. Detachment from the institutional church gives rise to a decrease in overall religiosity with a noticeable decline in the orthodox Christian bdief.

The characterisation of the secularisation process within Ireland is important given the fusion of religious and national identification throughout the last century. Ireland, a supposed anomaly to the rest of Western Europe, has to some degree let secularisation filtrate through society and the results are becoming more apparent with each research study conducted on 


\section{Mll Macrothink}

Journal of Sociological Research

ISSN 1948-5468

2009, Vol. 1, No. 1: E6

the topic. To understand the extent of the secularisation process in Ireland, three positions must be addressed - the macro empirical, the micro historical and the micro community/anthropologic.

At the macro empirical level Greeley and Ward's (2000) research 'How secularised is the Ireland we live in?' combines the International Social Survey Programmes second survey module on religion with the four European Values study's (1981, 1990, 1991, and 1998) to analyse past trends in religious behaviour and belief amongst Irish Catholics. Basic religious beliefs had little change between each survey carried out. A rise of four percent, however, in those that identified themselves as having no religious affiliation was noted. In accordance with this religious identification, church attendance in Ireland during the 1990s had no significant change. Greeley (1995) argues the importance of religious imagery in understanding religion. Following this, Greeley and Ward (2000) noticed a shift within the imagery of God in Ireland towards a more ancient loving and gracious God of love. The dichotomy of 'believing without belonging' (Davie 1994) appeared as young people identified themselves as been religious but do not attend mass, or furthermore, have confidence in the ecclesiastical institution. How secularized are Irish Catholics depends on the definition that you attach to both the concept of 'religion' and 'secular'. Greeley and Ward's (2000) research portrays the Irish situation as not been secularized. Irish Catholics demonstrate high levels of faith, high regard for their local priests and religion shapes their moral decision making.

Inglis (1987, 1998, 2007) and Nic Ghiolla Phadraig's (1995) work form the second strand the macro historical element. Inglis' (2007) work demonstrates the fusion of religious and national identities. The strong sense of Catholicism and religiosity is identified in his work and these two elements provide an understanding of the association of the Catholic Church and the Irish population from a historical perspective. Inglis highlights a decline in overall church attendance figures (Inglis 2007). These figures, however, in comparison with other European countries are relatively high.

Nic Ghiolla Phadraig's (1992) research 'Religion practice and Secularisation' is contradictory to Inglis' findings in that she posits the strongest aspect of religion in Ireland is religious practice. Social relationships were supportive of religious beliefs which are important to note given the importance of social networks in the study of religion. Nic Ghiolla Phadraigs research 'The power of the Catholic Church in the Republic of Ireland' (1995) correlated with Greeley and Wards (2000) findings - the majority of Irish Catholics prescribe to the Church's teachings in moral decision making such as abortion. Given the decrease in the structural power of the Catholic Church over political, media, education and civic life in general Nic Ghiolla Phadraigs research is supportive of Irish Catholics both possessing beliefs and belonging.

The third strand, the micro community/anthropologic aspect, Taylor (1996) and Scheper-Hughes (2001) research is imperative. This element moves beyond basic levels of faith and participation to analyse the importance and meaning that Irish Catholics attach to religious objects, people, places and even terminology and imagery. Taylors (1996) 
community based research 'Occasions of faith' illustrates the importance of this meaning-construction process for the individual and the community. It reinforces religion in everyday living and everyday experiences usually incorporate some type of religious association usually through meaning attachments or as Taylor terms it 'occasions'. Scheper-Hughes (2001) research 'Saints, scholars and schizophrenia' moves beyond Taylors work to analyse the institutional effects of Catholicism and their rituals on society and the individual. This community based research exemplified rural life. The cultural decline and widespread anomie reinforced through the churches institutional power at that time left communities eroded. The situation further resulted in parish members feeling trapped by circumstances which left them open to high levels of stress which in some cases resulted in schizophrenia. The importance of this study and the reason I refer to it is that it demonstrates the strong values and beliefs of a rural deprived area and the possible effects traditional beliefs have on the community. Within this strand, the primary aspect is the individual, the imprint of religion on the individual and in turn the effect that this has for a community as a whole.

Within these three strands of research the general consensus (except for Inglis (2007) research) is in sharp contrast to Davies (1994) 'believing without belonging' theory. At all three levels, Irish people possess relatively high level of religiosity and Nic Ghiolla Phadraig's (1992) research illustrated high levels of religious practice. Devotion to the Catholic Church has changed since the late twentieth century and particularly in the twenty-first century - which could explain Inglis' (2007) research findings. This is apparent in Ireland alongside the rest of Western Europe but this does not necessarily translate to secularisation.

Historically, the Catholic Church was strong, influential and powerful in Ireland. Through a contemporary analysis the situation that currently exists is in sharp contrast to that. Davies (1994) 'Believing without belonging' theory seems to characterise the Irish situation as demonstrated in the findings of the European Values Study data. The cross-cultural comparisons proved to be revealing in that $76 \%$ of Irish Catholics perceive themselves as been religious which is quite high in comparison to France and Spain but worryingly low in comparison to the Italians. However, it is in the translation from believing to practice/participation/belonging that Davies theory (1994) is most relevant. Religious practice has steadily declined in the past thirty years or so. A national survey carried out in 1973-74 found that over 90\% of Catholics in Ireland went to mass at least once a week (Inglis 2007). This is in stark contrast to the findings of The European Values Study that found only 66\% now attends mass weekly. $66 \%$ of Irish Catholics attend mass weekly yet $76 \%$ declare that they would perceive themselves to be religious. People possess high levels of religious belief but fail to translate these beliefs into actual institutional religious practices (Davie 1994).

\section{Methodology}

Qualitative methodologies -

"The study of people in situ is a process of discovery. It is of necessity a process of learning what is happening. Since a major part of what is happening is provided by people in their 
own terms, one must find out about those terms rather than impose upon them a preconceived or outsiders scheme of what they are about. It is the observer's task to find out what is fundamental or centre to the people or world under observation" (Lofland 1972:4; Patton 2002:28).

Qualitative methodology is a suitable approach to the exploration and detailed analysis needed for this research. Notably, one can capture the data in its natural setting, thus permitting the researcher an unimpeded perspective of the situation. My research question involves the need for in-depth analysis of personal experience, opinions, meanings, and attachments to the Catholic Church. By availing of the qualitative approach it allows for an analysis of the data in response to the secularization debate. The analysis of this further permits the testing of Davies (1994) 'believing without belonging' theory and its applicability to the Irish local level. Due to the nature of this study I chose to conduct semi-structured interviews.

\section{1 Semi-structured interviews}

"Without a doubt, the most utilized data collection method in qualitative research studies is the interview" (Rogers and Bouey 1996:52).

Semi structured interviews, or as Ryan \& Bernard (2000) refers to as 'Elicitation techniques', are in essence somewhere between structured and semi-structured interviews. The researcher possesses an interview guide, main questions or areas that they want to discuss (Flick 1998:76). However, these are just a guide and the flexibility of this technique allows the participant to speak freely, thus, generating information that the researcher can then develop on. The flexibility of the interview strategy generates constant reflection both on the researcher and research. Rubin \& Rubin (1995) highlight that -

"Adjusting the design as you go along is a normal, expected part of the qualitative research process. As you learn how the interviewees understand their world, you may want to modify what it is you are studying and rethink the pattern of questioning. Such flexibility is much better than persisting in a design that is not working well or that doesn't allow you to pursue unexpected insights". (P. 44)

As mentioned previously, the basic principle of qualitative research is to view the social world through the eyes of the participant. Open-ended questions are the ideal method to establish such a structure. The purpose of open-ended questions provides the researcher with the scope needed to gather responses that will capture the participant's views of the social world and social actors around them. Patton (2002:21) illustrates Loflands (1972:7) sentiments on this -

“To capture participants 'in their own terms' one must learn their categories for rendering explicable and coherent the flux of raw reality. That, indeed, is the first principle of qualitative analysis".

It is imperative that the researcher provides the framework for which participants can give detail on their views. As Denzin (1978b:10) states "too often social scientists enter the field 
with preconceptions that prevent them from allowing those studied to 'tell it as they see it'” (Patton 2002:21). The researcher's role in both the research and evaluation is critical. If a deductive method is utilized then questions are constructed to focus around the research area and to get quality data that can be evaluated and applied to the phenomena been explored. Therefore, the structure of the interview was divided into sections which corresponded with various themes that I felt needed to be examined. All of which would provide a better understanding of the extent of religiosity the community possess and, subsequently, an analysis of the extent of secularization at a local community level.

\subsubsection{The sample}

Sixteen interviews were conducted within the parish of Conwall and Leck, Letterkenny. The sample was divided into nine women and seven men ranging in age from eighteen to eighty five. Fourteen were Irish and two were foreign nationals - both Polish. The individuals who participated in the interviews were not chosen for their gender or age but rather for the fact that they are situated within this parish. Three priests were interviewed and the rest of the sample consisted of lay people, some members of parish organizations/groups others are simply members of the parish who do not have any particular affiliation to parish groups. The aim was to have a correct and appropriate representation of the parish as a whole, taking account of the different groups within this community and also bearing in mind the particular themes that needed to be examined. The sample encompassed all age groups from teenagers to the elderly, all of whom have different commitments and affiliation to the church. Thus providing a wider range of opinions and varying degrees of belief and belonging.

This particular parish was chosen as it is situated in a rural area of Ireland, Co. Donegal. In comparison to other towns throughout Ireland Letterkenny is relatively rural. However, it is rapidly expanding and with diasporic communities located within this town it has many of the characteristics that I wanted to research, analyze and understand.

\section{Findings and Analysis}

\section{The extent of religiosity amongst Catholics in Letterkenny}

\section{Part I}

Initially, I would like to draw attention to the socialisation of the Catholics that were interviewed, those who influence/impacted on their religious life and the extent of their religiosity. This will provide an overview to the background of their religiosity. I then will highlight their participation in mass, attendance, and parish group activities; and, furthermore, the meanings they attach to each of these. I then move on to analyse their hypothesis and judgements of their own Catholicism. Finally, I draw upon their own conclusions regarding Catholicism in Ireland and the secularisation process.

\subsection{Socialisation}

Socialisation into the catholic way of thinking of the world is an important aspect of an individual's religiosity. To be socialised into Catholicism, undoubtedly, would impact on an individual and their way of life. It could be the basis of a person's religion and faith if 
socialisation occurs at a young age. Socialisation, with respect to the interviewees, occurred in various ways and was initiated by different people. Interestingly, thirteen interviewees stated that at least one member of their family were involved in socialising them into the Catholic way of thinking. Two interviewees highlighted, also, their primary schools role in this process.

Father C (66): In addition to my parent's role in the socialisation process, the primary school I attended was, of course like all primary schools in the area at that time, a Catholic school. Prayers were said every morning, before break and lunch and after break and lunch. Strong emphasis was placed on God and the Catholic teachings.

Three interviewees believed that they had not been socialised into the catholic way of thinking. However, one of these three interviewees was in fact socialised into the catholic way of thinking but at a later stage of their life and due to difficult circumstances.

Women L (62): When I was young my parents were not religious so I was never socialised into the catholic way of thinking. However, I am now fully socialised into the catholic way of thinking of the world. When I was in my late forties I attempted to commit suicide to ease the pain. I was unsuccessful in my attempt. A priest saved my life. He sat with me in hospital and we talked and he read the bible to me. He helped me to find God. When I did find God my life turned around.....

Six interviewees highlighted that both their mother and father played a role in this socialisation process. While only one interviewee stated that their father was the most influential person in this process.

Father A (38): My father was an undertaker. Because of this I was constantly surrounded by death. It's something that I had to be comfortable with from an early age. My father taught me about God, dying, heaven and hell, and the catholic teachings, and how to always lead a good catholic life. As far as I can remember back my father talked to me about these things. He prayed the angelus with me every evening at six o clock, made sure I said my prayers morning and night. He was a very religious man; he could quote straight from the bible. He was the person I would say who socialised me completely into the catholic way of thinking.

Four interviewees asserted that their mothers had played a significant role in the process and two interviewee's grandparents were the most influential in socialising them into the Catholic way of thinking. One interviewee included her uncle (who is a priest) as having an influential role in her socialisation into Catholicism.

It is evident that the families' role in the socialisation process of their children into the Catholic world is quite significant. It would appear that those whose parents influenced this socialisation process into the Catholic way of thinking about the world; through different activities such as prayer, bible reading, mass attendance have kept their faith and, furthermore, religion still plays an important part in their daily lives. Those who were not socialised into the Catholic Church and the catholic way of thinking about the world have remained to possess low levels of religiosity. 
Interestingly, all of the interviewees believed that it was both positive and important for children to be socialised into the Catholic way of thinking. This was intriguing as even those who were not, themselves, socialised into the Catholic way of thinking about the world believed it was an important aspect of a child's life and development.

Man G (34): Well yes I think it is important, I've kids of my own and we rear them in a Catholic way. I'm not religious myself and I was never really socialised into the Catholic way of thinking about the world as a child but I think it is important that my kids be.

\subsubsection{Influences on their religiosity/religious life}

This element closely correlates with the above topic. However it is worth analysing separately as a few notable points were highlighted to me through the responses given. For the most part, the interviewees reiterated that their family had impacted positively on their religious life. Interestingly, two people illustrated the significant role that their community played in influencing their religious life. These responses were given by two elderly interviewees; eighty five and sixty three years of age respectively. Community studies have demonstrated the significant impact that community bonds and ties have on those within it, both in positive and negative respects. Religion is situated within both the public and private spheres; therefore it is convincing that community bonds may influence the religious lives of those who are situated within the bounds of a community. Letterkenny, six or seven decades ago was a very close knit small community.

Woman O (85): Everybody knew everybody; doors were left open without any worry. Religion was not something that was debated back then, priests and bishops were powerful, and people were almost frightened of them. Everybody was the same, they didn't have much and what they had they shared among the community. So everybody went to mass, said the angelus and rosary, prayed and the likes. It was unthinkable not to be a part of that. So when you are a part of something like that it definitely influences you.

This demonstrates the importance of social networking within communities. Individuals were influenced to be similar; differences were frowned upon or condemned. Individual's need to 'do the right thing' and to be fully integrated into communities depended on the extent of involvement within the community, with respect to the religious institution. This was vividly exemplified by Father B (priest - sixty three) who stated that:

"My mother and all the women from our row would be involved in cleaning the cathedral, bringing fresh flowers to the Bishops palace and bringing flowers to the altar. All the local women would be involved in this and it was done very regularly. Religion was so important to people that they all wanted to be involved in the parish duties. Of course no one asked them to do this it was a... a sort of tradition that they carried on from their own mothers".

Community life was both intense and concentrated in this particular time period. This combined with the power and widespread belief and dedication to the Catholic Church resulted in one effectively influencing the other. The compatibility of this relationship consequently affected and influenced the individual's religious life. 


\subsubsection{Generation differences}

It is argued that generational differences exist regarding the extent of religiosity and faith possessed. This argument is strongly associated with the secularisation debate in Western Europe. The lack of dedication both in the sense of belief and practice is considered to have declined significantly. Granted there is data to support this hypothesis such as the European values study (1981-2004). However, from my research it is clear that generation differences may not necessarily be significantly different at a rural level. If there is a difference in this generation's religiosity to past generations why is this necessarily viewed as negative?

The Catholic Church's loss of unquestioned power and influence in the middle of the twentieth century is for the foremost depicted in a negative way. Was this loss an automatic failing by the church, was/is it actually a destructive feature, does it in fact indicate a decline in the catholic population and dedication?

Father $C$ highlights that the decline in the church's overall power within the state is positive. The fact that people can question aspects of Catholicism nowadays means that they have a channel available to them to acquire a deeper understanding of Catholicism and spirituality.

Father C (66): Who can actually say this current generation is not as religious? Because people question different aspects of the bible or of the teachings does not mean that they are any less religious. Look at past generations, they believed undoubtedly, maybe because of fear of the Catholic Church or reprisal from the community. Regardless of the reasoning, they did. They weren't able to ask for scriptures to be explained, to question heaven, hell or purgatory. This generation can. The Catholic Church's lack of power...well I see it as a good thing. People aren't afraid anymore...

Interviewer: Afraid?

Father C: Yes afraid... of priests and bishops... It is not a problem for young people to come up to a priest and ask questions. This generation is curious. They want to understand everything, of course they can't understand everything but they'll make an attempt anyway...(laugh)... what I'm saying is, because they are willing to seek greater understanding they are getting better educated about the catholic teachings. They understand it more. Therefore, of course it could be argued that they are more religious because they have a better understanding. There's two ways to look at everything!

Interestingly, two other interviewees reiterated these sentiments regarding the Catholic Church's loss of outright control on society. Again, these interviewees did not consider this as negative. Undoubted faith is not the key to a successful faith. Understanding and developing people's beliefs and faith should in fact increase religious belief. One of these two interviewees has lived through, and experienced, the change in the structures of the Catholic Church. A change in the structure of the catholic teachings is one noticeable difference between generations. Globalisation is widespread and its effects ripple throughout every part of Ireland; rural areas included. The Catholic Church, it could be assumed, is simply adapting to the times. With mod cons, gadgets, internet and television the Catholic Church has to adapt to this generations needs. This is used to the advantage of the Catholic Church in Letterkenny. 
Man E (74): They now have special radios that you get from the cathedral. It transmits every mass, funeral, marriage and things like that. Everything that is celebrated in the cathedral we can listen to through our wee radios. It's brilliant. If I'm sick or my backs playing up someday and I can't get into the cathedral I can just turn on the radio and celebrate the mass along with the priest in my own house.

Interestingly, the two teenage interviewees both stated that they believed there are generation differences regarding Catholic faith. They both gave details on how, in their opinion, no one attends mass anymore. When asked if they attend mass both stated 'yes'. Both described that their parents 'make' them attend mass weekly as a family. Significantly and most notable was the following response given by one of these teenage interviewees.

Woman N (19): I'm made go every Sunday morning with my family...suppose I don't mind it too much 'cause all my friends are there anyway.

Interviewer: Do you meet them at mass?

Woman N: Well aye if I see them after we'll have a chat but it depends I mightn't even see them cause it's always packed at half twelve mass.

This teenage interviewee portrays, initially, that generation differences was evident by the lack of people attending mass nowadays; decline in those who actively participate in their faith. Yet when further probed she stated that all her friends attend Sunday mass. Furthermore, there is a large presence at this specific sermon on a Sunday morning. Perhaps there is a fixed mindset among the younger generation that they are less religious. The media's presentation of secularisation features regularly on both television and radio programmes, which filters into the minds of the younger generation from an early age. One could presume that secularisation is taken for granted and unquestioned/unchallenged by the younger generation.

\section{2 Mass Attendance and Meanings Attached to This}

Distinctly none of the interviewees asserted that they completely did not or do not attend mass. It is evident from the interviews that these individuals acquire meaning from the sermons and attendance at mass, to different extents, but nonetheless provide them with personal meaning. Regardless of age and gender, meanings are attached to every aspect of society and can be felt by every individual. Mass attendance and the meanings it has and provides people with can be felt at different levels; the individual private level and a more public level where the congregation has shared meanings.

Interestingly, with the rise in religious pluralism and diasporic communities on the increase, the polish interviewees felt and obtained great attachment to the community from attending mass. Catholicism is an embedded part of their life. Due to the fact that ethnic similarities are present this could explain the integration and attachment to this community. They attend the mass which is celebrated in their native tongue fortnightly but they also attend Saturday evening mass weekly. Feeling part of the community and welcomed is something that is extremely important to them.

Man D (29): We attend mass so we are closer to god. We want to hear the word of God. 
Something we can keep with us for the week......

Going to mass has a lot of meaning for me. Feeling part of this community, while sitting with everyone else, saying the same words, celebrating the same mass is overwhelming for me. I feel accepted. Everyone can get something from attending mass. But what is most important to me is feeling a shared identity, you know everyone been the same, no difference no matter what color or nationality you are, when you are at mass were all the same, were not only Letterkennys community but the community of God.

Identity construction in the form of Catholicism is created by mass participation. They all have a common bond - the same religion, the desire to hear and do God's will.

A common feature was the notion of comfort and afterlife amongst the elderly interviewees (for this research the elderly interviewees are classified as been sixty or over). It would appear that the term 'need for Gods comfort' is associated with age. Other interviewees referred to obtaining comfort and hope from God in times of crisis but the term 'need for God's comfort' was distinctly utilized only by the three elderly interviewees. Both of the teenagers express the meaning that they acquire from attending mass is the contemplation of getting assistance from God, their guardian angel and saints. Initially, it would appear to be different to the sentiments of the elderly interviewees who acquire peace and comfort from God; the teenagers require what is relevant to them in their lives. The response given by woman $\mathrm{O}$ highlights that salvation in the 'next life' seems to be a concern amongst the elderly interviewees opposed to that of the younger interviewees. Interestingly, one referred to the examination period and seeking guidance and miracles from God; an almighty power almost. This articulates that they receive feelings of self good and worthiness when they attend mass. They gain strength and guidance for examinations through participating in mass and prayer. This is similar to what the elderly interviewees desire, the only difference been the context and situation that it is required for.

The feeling of connection to God and deep spirituality was also referred to in responses. The desire for inner peace and guidance is something that people can achieve through prayer and mass attendance.

Woman L (62): When I go to mass, which would be three or four times a week, I get...I feel connected to God. I feel He knows what I'm thinking, what I need, my problems and all. The spirituality that I feel throughout the sermon is just wonderful, I love going to mass, I love to have that feeling of deep spirituality with God. That's the meaning that I get from going to mass.

The fact that all of the sixteen interviewees, ranging in different ages and backgrounds, participate and attend mass is an indication of the extent of religiosity and belonging within this community. By attending and participating in the mass each individual is, provided almost, with meanings that is relevant to them and their life at that particular time. Interestingly, all of the interviewees seek to find meanings behind attending mass, they all feel and desire spirituality, guidance, comfort, help and to some degree peace. Most significantly is the fact that the Catholic Church, through sermons, provide the community 
with the meanings that they require.

\section{3 Parish group activity and meanings attached to this}

Davie (1994), along with other theorists has hypothesized a decline in the active participation amongst Catholics. Level of beliefs does not correlate to church participation. Therefore an appropriate measure to account for this community's actual involvement in the church was done through examining how often they attend mass and the meanings they attach to this participation. In addition to this, I questioned whether they were involved in any parish groups so as to obtain a deeper and real understanding of the extent that they actually participate and if this infact corresponded with their level of belief.

For the most part, those who would be classified as religious through different variables such as mass attendance and socialization into the catholic way of thinking of the world are actively participating in the Catholic Church in the form of parish groups. These parish groups range from prayer meetings to alter societies but regardless of which parish group they are involved in the fact remains that they are actively participating. Not all interviewees are involved in parish groups however. Those that classify themselves as not been religious (yet some still attend mass - this will be discussed further in the next section) are not, and have not been, engaged with any parish group. There is only one interviewee that would classify themselves as "not really religious"; does not attend mass regularly and is not a member of any parish group.

Woman P (28): No I' not involved in any parish groups, I don't go to mass often to find out about what groups there are within the cathedral so...no not a member of any.

Two other interviewees stated that they were not involved in any parish groups. These two individuals declare themselves to be non-religious yet they both attend mass regularly. This highlights the level of participation, and to a certain extent, this is greater than the level of belief. Thus, this supports the contradictory hypothesis - belonging without believing opposed to Davies (1994) 'believing without belonging' theory.

One teenager who would not classify herself as completely religious but does attend mass is infact also involved in a parish group.

Woman N (19): Yeah I'm part of the young adult prayer meeting group. We meet once a week for an hour...we'll I don't go every week but I go with my friends, suppose we do go most weeks.

Interviewer: Is it important to you that your friends also attend?

Woman N: Well yeah, I wouldn't't go on my own!

This interviewee yet again highlights the importance of social networking to the religious institution and involvement within the Catholic Church. Already we have discovered that due to the fact that her friends attend mass on a Sunday she also attends with her family. Yet again, here, she illustrates that participation in this particular parish group is aided by the fact her friends are also involved. All of the other interviewees are involved in a parish group. The 
groups that were specifically mentioned varied- cathedral choir, Devine mercy, young adult prayer meeting, charismatic prayer group; altar society, legion of Mary and St. Pius X adoration chapel group.

Regardless of which parish group the interviewees were involved in they all stated that they experienced something from actively participating in the group. Whether they felt closer to God, a spiritual connection, part of the community, or peace the fact remains that religion still has something to offer each and every one of its members. It provides them with what they need. This is exemplified by their continuous dedication to their chosen parish group/s. This dedication demonstrates yet again the extent of this community's religiosity in both terms of believing and belonging.

\section{4 Personal Catholicism}

This question was posed in order to obtain a greater understanding of how the interviewees each would classify their own personal Catholicism; how the interviewees perceive the extent of their own religion in terms of believing and belonging. Moreover, it is interesting to observe if their own opinion of their religiosity corresponds with each of their own level of belief and participation. Within this, questions such as how often do they pray and go to confession, would you consider yourself an orthodox Christian and would they consciously refer to their faith daily were taken into consideration when summing up their own Catholicism.

Interestingly only two interviewees referred to themselves as been orthodox Christians. Significantly these were the two eldest participants. It is particularly interesting that these two interviewees stated that they possess high levels of religiosity and would consider themselves to be orthodox Christians. They are from an older generation, a generation that was ruled by the Catholic Church, a generation that did not question religion and who lived rigidly by the Catholic Church's teachings. They were socialized into the catholic way of thinking of the world from birth and seem to have maintained their religiosity throughout their lives. This is opposed to younger generations who did not witness the Catholic Church utmost power on society (Inglis 2005:67). They may have been socialized into Catholicism but in this contemporary society which can be seen in Letterkenny (modernization is clearly filtering into rural areas) been an orthodox Christian is not a prominent feature of this community.

Three interviewees classified themselves as not been 'good' Catholics. Two of these interviewees were teenagers. Significantly, one of these teenage interviewees attends mass weekly and is also a member of a parish group yet she does not classify herself as been a good Catholic. One would assume that this particular interviewee belongs without believing, or is it the fact that the youth of this generation do not like to admit that they are religious?

I was specifically interested in the responses given by the three priests; whether they would consider themselves to be orthodox Christians. They of course follow the teachings of the church without fault but when asked they wavered away from the question, preferring to discuss ‘orthodox Christianity' in society.

Priest B (63): I am a good catholic, but I suppose like everyone else I could be better. I do 
pray of course and attend confession and refer to my faith daily but as for considering myself an orthodox Christian, well I just don't know. It's very hard in today's society, you know to try and fit some of the teachings in. They are important don't get me wrong, but sometimes you just think if maybe they were adapted even slightly it might help. Not to help the Catholic Church to gain more support or members, I don't mean it like that, but for the family they already have...

This is a powerful and honest response which I think is significant. Rather than attempting to attract new members the church should focus on the members it already has and how they can assist them more. The crux of the church lies in its teachings, but perhaps when so many people cannot and do not want to refer to themselves as orthodox Christians because of the consequences and restrictions that this has on society and particular members/groups of society then perhaps the church should revisit some of their particular teachings.

From this analysis I do not think that whether a person would be classified as been an orthodox Christian or not has much bearing on their religiosity. Regardless of their own perceptions of their religiosity and whether they agree or disagree with the orthodox teachings of the Catholic Church the main variables in analyzing the extent of their religiosity is beliefs and participation. My main aim was to analyze the mindset of the interviewees; whether they themselves considered that they were religious and if these beliefs translated into participation.

\subsection{Thoughts on the existence of secularization}

I established this particular section of questions so as to acquire a general consensus of the community's ideas and opinions on the Catholic Church in Ireland today in relation to the secularization debate. It is important to verbalize the opinions of the lay people of a rural parish regarding the secularization debate and what they feel is occurring opposed to what a large scale social survey claims is occurring.

The secularization debate is, of course, a contentious issue especially with regards Ireland given its long standing alliance with the Catholic Church. Hence why, so much attention and research focuses on Ireland as an anomaly to the rest of Western Europe.

There was mixed responses to the existence of a secularization process occurring in Ireland. Again, only two respondents both believed that the Catholic Church was in decline and that the secularization process was definitely underway in Ireland. These two interviewees were both teenagers.

Man F (18): Yes I think secularization is happening. Nobody goes to mass anymore; well very few people and young people never go....

I think the Catholic Church is definitely dying....

Yeah they need to change been so strict on things like divorce and stuff....

People just have more things goin' on right now than been religious.

This I find to be very interesting. For me, this response echoes the sentiments of an individual 
who does not fully understand the term 'secularization' and again highlights the teenage culture of not wanting to be associated with religion or the Catholic Church. This interviewee previously stated that he does attend mass and seeks God's help leading up to examination times; yet he states here that nobody goes to mass least of all young people.

The other interviewees do not believe that secularization is occurring to any great extent as they have witnessed a packed cathedral every week for mass.

Woman K (40): No I think that the whole talk on secularization is a load of nonsense. I go to mass every week and the cathedral is jammed

One interviewee gave a very poignant response that I feel summed up the feelings on the secularization process in Ireland.

Priest B (63): Secularization is not a major cause for concern for the Catholic Church, it certainly does not signify the decline or end of the Catholic Church....religion in every generation and with every century had to face challenges and survived and grew from it, this is just this generation's challenge....

Davies (1994) 'believing without belonging' theory appeared to interest the interviewees. As religion moves from the public sphere to a more individualized feature Davies theory would appear to be of great value in today's society. Can you measure the level of religiosity through participation only?

Woman H (29): Believing without belonging that's very interesting. Well yes I suppose people can believe without belonging. With life been so hectic and having so much stress and things to do it is not always possible for people to go to mass regularly. But they may pray at night and in the morning or even quietly pray or speak to God during the day.

This highlights that religiosity can extend and penetrate deep into peoples' lives. Even though participation in the Catholic Church is extremely important, those who are not able to participate may still be religious and have strong beliefs. It would be unfair to measure an individual's religiosity simply through focusing solely on participation.

Religion faces many difficulties, each generation having to deal with, and work through their own. With cosmopolitan societies, globalization, pluralisation on the increase this does not necessarily mark the decline in the number of people who are catholic and believe and participate. Catholic communities are strong in rural areas of Ireland and within every city you will find catholic communities. Outside forces may infiltrate into communities and change the course of people's lives but what I found was that those who were socialized and influenced into the catholic way of thinking will continue their faith throughout their lives and pass this on to their own children. Religion clearly plays a large part in the lives of the people in this community. Regardless of what the modern world can offer when people are in times of difficulty they usually will turn to the church and God for help and guidance.

\section{6 Discussion and conclusion}

Davies (1994) theory 'believing without belonging' is a prominent feature in the 
secularisation literature. The adaptation of this theory as a means of rationalising or explaining situations within other contexts is problematic. A generalisation of a theory, as with the application of large scale social surveys, is a challenging and possible detrimental undertaking. Therefore, the analysis of the data collected provides an indicator or the level of relevance or applicability of Davies theory (1994) 'believing without belonging' to the Irish rural parish level.

So far, my research has demonstrated contradictory evidence to that of the European value survey and to some extent Davies theory. Is it possible to claim that Ireland is secularised or in the process of becoming secularised when religion is such an important part of the community's lives at a rural area? Therefore, I do not feel that it is possible to apply Davies theory directly to the situation at a rural level. It is, however, not that simple. I do not disregard Davies theory but do believe that it is important to the secularisation literature and could, to some extent, further my analysis of this rural community. Could it be stated that this community believes without belonging or is it in fact the case that they belong without believing?

My aim is to analyse the interviewees level of religiosity and if this corresponds with their level of participation in the church, thus inadvertently and consciously analysing Davies (1994) 'believing without belonging' theory and it's applicability at a rural local level. I will complete this in two steps- analysing the interviewees level of religiosity, to comprehend if they do infact 'believe'. Second, I will analyse their levels of participation in order to interpret if they 'belong'. Therefore, I will obtain a clear understanding of the situation in this rural parish with respect to Davies (1994) 'believing without belonging' theory.

The beliefs and belonging dichotomy tends to be an arduous and complex relationship. The relationship that exists between both does not necessarily maintain or encourage the other. Davie highlights from her findings that people tend to believe and have faith but do not belong/participate in the church.

Briefly, from the in-depth analysis carried out in part I the common consensus would be that those that were interviewed within this parish are quite religious. However, to analyze the extent of their religiosity in relation to their belief system (only for the time been) involves the inclusion of other variables such as their personal conceptions of their beliefs and their socialization into the catholic way of thinking. This is a brief synopsis of their faith; in order to obtain a clear concise picture of their overall religiosity it is necessary to focus on their participation and belonging to the church which I shall do.

All of the interviewees were socialized into the catholic way of thinking about the world except for one interviewee. This provided the foundation of their religious beliefs. The one interviewee who claimed that he was not socialized into the catholic way of thinking about the world and did not believe that he was a religious man did state that he is rearing his own children to be Catholic. This demonstrates that although he, himself, was not socialized into the catholic way of thinking about the world and was reared with no religious background one could surmise that he must believe that it is important if he is raising his own children to be Catholic. These beliefs that were transferred or passed down from their mothers, fathers, 
uncles or grandparents provided each of the interviewees with a base on which to build and maintain their faith. Each clearly had 'belief'; the question remains - how did this transfer to 'belonging'?

The interviewee's level of belief is represented and identified through the extent of their participation in the church. Mass attendance is high amongst the interviewees. All of the interviewees attend mass regardless of their religiosity, or how they view their own Catholicism. Attending mass stimulates meaning for each interviewee, to varying degrees. However, it is interesting that some of the interviewees do not attend mass of their own accord or regularly. Man G, who was not socialized into the catholic way of thinking or does not classify himself as religious, attends mass weekly with his family. Both teenage interviewees, woman $\mathrm{N}$ and man $\mathrm{F}$ attend mass weekly but both states that they attend with their family, it is not by choice. In addition, woman $\mathrm{M}$ and woman $\mathrm{P}$ both in their twenties do not attend mass regularly. They attend mass only when they are in Letterkenny. However, regardless of the frequency of mass attendance or the reasoning behind attending mass each interviewee highlights that they get a sense of meaning from participating. This is important as it encourages participation regardless of level of belief. This is significant as it, on the contrary to Davies (1994) 'believing without belonging' theory, emphasizes a pattern of belonging without believing.

To comprehensively analyze the accuracy of this statement other activities that involve participating in the church must be examined. Participation in parish groups yields very noteworthy results. Not every interviewee is involved in parish groups. However, ten people out of the sixteen interviewees are members of a parish group. One interviewee was a member of a parish group before she went to university and another interviewee attends the St. Pius X adoration chapel regularly but is not a member; while one interviewee was a member of the chapel choir group before she went to university. So infact, thirteen out of the sixteen interviewees are affiliated with a parish group to some degree (at some stage of their lives). Three interviewees are not associated with any parish group; fascinatingly two of these are man $\mathrm{F}$ and man $\mathrm{G}$ both of whom do not classify themselves as religious but attend mass regularly. Man F also admitted to praying and seeking God's guidance especially during examinations.

'Belonging' also encompasses additional aspects of participation than the two aforementioned - mass attendance and parish group membership. During the block of questions regarding their opinions on their own Catholicism I questioned the interviewees on their confessional attendance. Eight out of the sixteen interviewees do not attend confession and have not done so in a long time. Those that do attend confession include three priests, a parish group member and a married woman, all of whom have strong religious backgrounds.

Orthodox Christianity would appear to be in decline, with even the interviewees who possess the strongest of religious backgrounds questioning it. However, there are a small amount of interviewees who classify themselves as been orthodox Christians; these mainly been the older interviewees. Regardless of whether a person can or cannot be classified as an orthodox Christian, the fact still remains that Davies theory (1994) 'believing without belonging' does 
not represent the situation in this rural parish. From a close analysis of the sixteen interviews carried out it would appear that the majority of the interviewees both believe and belong. However, there is a strong presence of people belonging without believing. The situation in this parish would appear to be in stark contrast to that of Davies theory (1994). Davie illustrates that the current situation in Britain (which is mirrored throughout Europe) represents high levels of belief along with low levels of belonging/participation. In contrast, at this rural local parish level the community has a strong sense of belonging to the church; regardless of the level of belief. Nevertheless, for the majority of the interviewees the 'belief' is also present, deep-seated and strong. Therefore, the 'belief' aspect of Davies theory is accurate and can emulate the situation in this parish.

Micro level research can be the starting point for re-examining the secularization debate in the twenty-first century. Widespread changes are taking place and it may be time to re-address the secularization thesis from a modern perspective. Micro level research can be built upon and national contexts can be re-evaluated. For example, if one looks at the situation within America over 35 million non-nationals reside there. Religion is a key feature of immigration and immigrants possess high religious belief and belonging (Levitt 2007) (also briefly mentioned in my research through the two Polish interviewees). This is evident by the fact that over $90 \%$ of the American people have belief in God. With national contexts and religious landscapes growing in diversity the secularization phenomenon is no longer easily adapted to national contexts or at any level. My research at a parish level reveals high levels of religiosity which is represented through participation within the church. Davies theory is important to modern secularization literature but the theory cannot be applied wholly to this local situation; an examination of religion at a local level proves to yield contradictory evidence to that of the secularization thesis. This, I posit, could illustrate a need to re-examine religion in terms of both the levels of belief and participation nationally in response to cultural and religious changes at a national and international level.

\section{References}

Berger, P., \& Luckmann, T. (1966). The Social Construction of Reality. Garden City: Doubleday Anchor

Berger, Peter L. (1967). The Sacred Canopy: Elements of a Sociological Theory of Religion. Garden City, NJ: Doubleday.

Berger, Peter L. (1990). The Sacred Canopy: Elements of a Sociological Theory of Religion. Anchor

Bruce, S. (1997). Religion in the modern world. Oxford University Press

Davie, G. (1994). Religion in Britain since 1945. Believing without Belonging. Oxford: Blackwell

Denzin, N. K. (1978). The research act: A theoretical introduction to sociological methods (2nd Ed.). New York: McGraw-Hill.

Dobbelaere, K. (1985). Secularization theories and sociological paradigms: A reformulation 
of the private-public dichotomy and the problem of societal integration. Social analysis, 46:4, 377-387

Dobbelaere, K. (1999). Towards social integrated perspective of the processes related to the descriptive concept of secularization. Sociology of religion, 60:3, 229-247

Duffy, E. (1992). The stripping of the altars: traditional religion in England c. 1400- c. 1580. Yale University Press

Flick, U. (1998). An introduction to qualitative research. London: Sage.

Greeley, A., and Ward, C. (2000). How Secularised is the Ireland We Live In?, Doctrine and Life, 50:10, 581-617.

Greeley, A. M. (1995). Religion as poetry. New Brunswick, NJ: Transaction Publishers

Guba, E. G., \& Lincoln, Y. S. (1981) Effective evaluation: improving the usefulness of evaluation results through responsive and naturalistic approaches. San Francisco: Jossey-Bass.

Inglis, T. (2007). Catholic identity in contemporary Ireland: Belief and belonging to tradition. Journal of contemporary religion, 22:2, 205-220

Inglis, T. (1987). Moral Monopoly: The Catholic Church in Modern Irish Society. Dublin: Gill \& Macmillan

Inglis, T. (1998). Moral Monopoly. The Rise and Fall of the Catholic Church in Modern Ireland. Dublin: UCD Press.

Levitt, P. (2007). God needs no passport. New York: NY: New Press

Lofland, J. (1972). Analysing Social Settings. Belmont: Wadsworth

Luckmann, T. (1967). The invisible religion. New York: Macmillan

Mills, C. W. (1959). The Sociological Imagination. Oxford: Oxford University Press

Nic Ghiolla Phadraig, M. (1992). 'Religious Practice and Secularisation', in P. Clancy, S. Drudy, K. Lynch and L. O’Dowd (Eds) Ireland: A Sociological Profile, pp. 137-54. Dublin: Institute of Public Administration in association with the Sociological Association of Ireland

Nic Ghiolla Phádraig, M. (1995) 'The Power of the Catholic Church in the Republic of Ireland', in P. Clancy, S. Drudy, K. Lynch, and L. O’Dowd (eds.) Irish Society: Sociological Perspectives, Dublin: Institute of Public Administration, pp. 593-619.

Parsons, T. (1974). Religion in Postindustrial America: The Problem of Secularization. Social Research, 41:2,193-225.

Patton, M. Q. (2002). Qualitative evaluation and research methods (3rd ed.). Thousand Oaks, CA: Sage Publications, Inc.

Rogers, G., \& Bouey, E. (1996). Collecting Your Data, In L. M. Tutty, M. Rothery, R. M. 


\section{Macrothink}

Journal of Sociological Research ISSN 1948-5468 2009, Vol. 1, No. 1: E6

Grinnell, Jr. (Eds.), Qualitative Research for Social Workers: Phases, Steps, and Tasks (4th ed.), (pp. 50-87). Boston: Ally \& Bacon

Rubin, H. J., \& Rubin, I. S. (1995). Qualitative Interviewing: The Art of Hearing Data. Thousand Oaks, CA: Sage

Ryan \& Bernard, 2000. Data Management and Analysis Methods. In N. Denzin and Y. Lincoln $\left(2^{\text {nd }}\right.$ Ed) Handbook of Qualitative Research, Thousand Oaks, CA: Sage Publications, 769-802

Scheper-Hughes, N. (2001). Saints, scholars and schizophrenia, mental illness in rural Ireland. University of California press

Taylor, Lawrence. (1996). Occasions of faith. Dublin: lilliput P

Troeltsch, E. 1958 [1912]. Protestantism and progress. Boston, MA: Beacon Press

Wallace, Anthony F.C. (1966). Religion: An Anthropological View. New York: Random House

Weber, Max. (1958). The Protestant Ethic and the Spirit of Capitalism, trans. Talcott Parsons. New York: Scribner's. (Orig. pub. 1904-5; revised 1920; trans. orig. pub. 1930.)

Wilson, Bryan. (1985). Secularization: The inherited model. In P. Hammond (1985), The sacred in a secular age (pp.9-20). Berkeley: University of California Press 